ПЫРМА Роман Васильевич - кандидат политических наук, доцент департамента политологии факультета социальных наук и массовых коммуникаций Финансового университета при Правительстве РФ (125993, Россия, г. Москва, ГСП-3, Ленинградский пр-кт, 49; ругта@таil.ru)

\title{
ТЕОРЕТИЧЕСКИЕ АСПЕКТЫ ИССЛЕДОВАНИЯ ПОЛИТИЧЕСКИХ ПРЕДПОЧТЕНИЙ РОССИЙСКОЙ МОЛОДЕЖИ
}

\begin{abstract}
Аннотация. В статье представлен обзор научных подходов к исследованию политических предпочтений молодежи. Актуальность темы продиктована предстоящим избирательным циклом. Молодежь рассматривается как социальная группа, потенциально расположенная к значительному росту электоральной активности. Электоральные предпочтения молодежи характеризуются выраженной позицией, принятие решений происходит в пользу определенного политического субъекта, обладающего комплексом идей, ценностей и ресурсов. Движение социальных настроений и политических предпочтений молодежи на предстоящих федеральных выборах обусловлено социализацией поколения, социально-экономическими изменениями, растущим влиянием цифровых коммуникаций и предложенным образом будущего.
\end{abstract}

Ключевые слова: молодежь, политические предпочтения, электоральное участие, политические коммуникации, избирательный цикл

$\mathrm{B}$ ысокая актуальность темы обусловлена несколькими обстоятельствами, заставляющими пересмотреть устоявшееся представление о российской молодежи как политически пассивной социальной группе. Прошедшие в сентябре 2016 г. выборы в Государственную думу России и в марте 2018 г. - выборы президента России показали возможности политической мобилизации избирателей в целом и существенное повышение электорального участия молодежи в частности. На президентских выборах молодежь участвовала в голосовании даже более активно, чем другие возрастные группы избирателей ${ }^{1}$. Результаты этих выборов президента России ставят под сомнение устойчивость абсентеистских настроений молодежи и ее характеристику как «неголосующего поколения» из-за отстраненности от политики и отсутствия сформированной традиции электорального участия. Оформляется тенденция роста гражданской активности и политической субъектности молодого поколения. В перспективе предстоящего избирательного цикла молодежь как социальная группа, показывающая растущую электоральную активность, приобретает для политических игроков особое значение. Исследование изменений электоральных установок, прогнозирование политического поведения молодежной аудитории становится одной из важнейших задач. Становится востребованной активная работа с молодыми избирателями, включающая политическое программирование и формирование позитивной повестки дня [Пырма 2019].

В современном обществе формирование ценностей и установок современной молодежи происходит в преломленной социальной среде. Социализация молодого поколения происходит под возрастающим влиянием цифровых коммуникаций, которые интегрируют также прежние информационные каналы. Основным источником получения информации для молодежной аудитории стали социальные медиа, а телевидение и радио заняли место второстепенных источников (см. табл. 1). Социальные медиа создают широкие возможности

1 Молодежь ломает стереотипы. 2018. Доступ: https://2018.wciom.ru/index. php?id=1242\&uid=9002 (проверено 15.07.2020). 
для манипуляции общественным мнением, инициирования и модерации протестных настроений. Опробованные технологии перевода протеста, организованного посредством цифровых сервисов общения и обмена информацией, на пространство улиц и площадей создают опасность дестабилизации политической ситуации. Переключение каналов коммуникации, возрастные особенности психологического развития, формируемые завышенные ожидания, социально-экономическая ситуация создают условия для смены политических настроений молодежи с лояльных на радикальные [Пырма 2017].

Таблица 1

\section{Распределение источников новостной информации среди граждан России по возрастным группам ${ }^{1}, \%$}

\begin{tabular}{|l|c|c|c|c|c|}
\hline $\begin{array}{c}\text { Варианты ответов на вопрос: } \\
\text { ४з каких источников вы чаще всего } \\
\text { узнаете новости, информацию?» }\end{array}$ & $\begin{array}{c}\text { Население } \\
\text { в целом }\end{array}$ & $\begin{array}{c}\mathbf{1 8 - 3 0} \\
\text { лет }\end{array}$ & $\begin{array}{c}\text { 31-45 } \\
\text { лет }\end{array}$ & $\begin{array}{c}\mathbf{4 6 - 6 0} \\
\text { лет }\end{array}$ & $\begin{array}{c}\text { Старше } \\
\mathbf{6 0} \text { лет }\end{array}$ \\
\hline Телевидение & 71 & 48 & 64 & 80 & 92 \\
\hline Новостные сайты в Интернете & 44 & 57 & 55 & 43 & 18 \\
\hline $\begin{array}{l}\text { Форумы, блоги, сайты социальных } \\
\text { сетей }\end{array}$ & 19 & 38 & 20 & 17 & 3 \\
\hline $\begin{array}{l}\text { Разговоры с родственниками, друзьями, } \\
\text { знакомыми }\end{array}$ & 17 & 17 & 19 & 18 & 12 \\
\hline Печатная пресса (газеты, журналы) & 12 & 6 & 7 & 12 & 25 \\
\hline Радио & 12 & 9 & 13 & 10 & 15 \\
\hline Другое & 1 & 1 & 1 & $<1$ & $<1$ \\
\hline Затрудняюсь ответить & 1 & 2 & 2 & 1 & 1 \\
\hline
\end{tabular}

Молодежи посвящен широкий круг научных исследований, рассматривающих молодежь как особую социальную группу, имеющую наибольший потенциал развития и определяющую будущее страны. Однако тематика исследований политического поведения молодежи не столь распространена. Российская молодежь характеризуется исследователями как электорально пассивная социальная группа, которой присущи абсентеистские настроения, пренебрежение своим избирательным правом [Малькевич 2007]. Вместе с тем она рассматривается как потенциально активная социальная группа, расположенная к протестным действиям [Ефанова 2011].

Электоральное участие молодежи исследуется как в социологическом, так и политологическом ракурсе. В социологических исследованиях М.К. Горшкова, Ф. Шереги, Ю. Зубок предпринята попытка определить систему ценностей, мотивов и установок, составляющих основу политического сознания и мотивации молодежи [Горшков, Шереги 2010а, 2010б; Зубок, Сорокин 2010]. Исследователи уделяют внимание формированию массового сознания молодежи, восприятию социальных противоречий российского общества и причинам низкой гражданской активности молодежи. Они исходят из необходимости управления жизненными стратегиями, формирования системы ценностей социальной группы молодежи в условиях общественных трансформаций. Социологи Л. Гудков, Б. Дубин, Н. Зоркая выделяют ряд особенностей полити-

\footnotetext{
${ }^{1}$ Источники новостей и доверие СМИ. Интернет как источник информации: практики и доверие. 2019. Доступ: https://fom.ru/SMI-i-internet/14170 (проверено 15.07.2020).
} 
ческого участия российской молодежи, исходя из «дефектной» социализации. Если по статистическим показателям ее активность не сильно отклоняется от показателей в большинстве европейских стран, то социальные роли разнятся - российская молодежь предпочитает позицию отстраненного зрителя [Гудков, Дубин, Зоркая 2011].

В политологических исследованиях молодежь выступает как субъект политического процесса. Электоральная активность молодежи предметно исследуется в работах О. Карпенко, Н. Беляевой и К. Устинкиной, в которых рассматриваются аспекты политической культуры, воздействие политических акторов на молодежную группу, феномен молодежного лидерства, проводится анализ политической активности молодежи, описываются технологии привлечения молодых граждан к участию в выборах [Карпенко, Ламанов 2006; Беляева 2014; Устинкина 2014]. В исследовании под руководством С.В. Чуева рассматривается степень вовлеченности молодежи в политику и ее протестный потенциал на основании ценностных установок [Ценностные ориентации... 2017: 34-39]. В работе Е. Сайгановой электоральное поведение молодежи рассматривается как детерминация политической культуры [Сайганова 2014]. Значительную часть работ по данной тематике составляют диссертационные исследования. Среди них следует отметить диссертацию Д. Бобровой, в которой рассматриваются социальные факторы управления поведением молодых избирателей [Боброва 2016].

Понятие общественно-политических предпочтений молодежи в научном знании теоретически не проработано и встречается по большей части в региональных исследованиях [Букин 2009; Будаева, Будаева 2012; Старцева 2013; Тимофеев, Пузиков 2014]. В исследованиях часто используются близкие по содержанию термины: политические интересы [Морозова 2015], политические ориентации [Бокарев 2008; Банникова, Боронина, Вишневский 2013]. В целом общественно-политические предпочтения понимаются как выражение позиции граждан в отношении оспаривающих власть акторов, значимых социальных проблем, идей и ценностей. Предпочтения избирателей обусловлены как мотивами рационального выбора, так и эмоциональными установками. Результаты социологических исследований электоральной активности и предпочтений молодежи в сопоставлении с другими возрастными группами находят отражение на порталах Всероссийского центра изучения общественного мнения (ВЦИОМ $)^{1}$ и Фонда «Общественное мнение» $(\text { ФОМ })^{2}$.

В свою очередь, политические ориентации состоят в направленности личности на определенные политические идеи и ценности, политические силы, определяющие мотивацию личности и ее поведение в политической сфере. В политической науке ориентации рассматриваются со стороны ряда подходов. В классической интерпретации Г. Алмонда политическая ориентация понимается как основа политической культуры, включающая ряд структурных элементов, таких как 1) когнитивные ориентации, т.е. знания и вера относительно политической системы, ее ролей и обязанностей относительно этих ролей, того, что система берет из окружающей среды и что дает; 2) аффективные ориентации, или чувства относительно политической системы, ее ролей; 3) оценочные ориентации - суждения и мнения о политических объектах [Алмонд 1992]. В одной из производных версий политическая ориентация определяется как соответствующие потребностям представления людей о целях политической

1 Выборы-2018. 2018. Доступ: https://wciom.ru/news/ratings/vybory_2018/ (проверено 15.07.2020).

2 Социальная и политическая активность молодежи. 2017. Доступ: https://fom.ru/ TSennosti/13286 (проверено 15.07.2020). 
деятельности и приемлемых средствах их достижения [Дилигенский 1994]. В другой вариации производится размежевание политических ориентаций, представлений и позиций исходя из возрастания рационального, эмоционального и волевого компонентов [Гавра, Соколов 1999]. На основании указанных подходов политические ориентации трактуются как направленность личности на избранные политические ценности, идеи, интересы, события, выступающие внешними факторами, воздействующими на мотивацию поведения индивида в сфере политики [Стегний 2016].

Прогнозирование электоральной активности относится к числу актуальных тем экспертного сообщества в период избирательной кампании. В работах А. Ахременко обозначены возможные методики составления электоральных прогнозов [Ахременко 2006]. Исследовательская группа ВЦИОМа во главе с Ю. Баскаковой проанализировала практику построения прогнозов в США [Баскакова и др. 2016]. Исследования В. Звоновского показывают применение социологического подхода в построении предположений [Звоновский 2011]. В статье Д. Петросянца и И. Юшкова представлен опыт рассмотрения динамики политических настроений студенческой молодежи [Петросянц, Юшков 2016].

Общественно-политические предпочтения распространяются на кандидатов, партии, институты, идеологии, программы, инициативы, акции, решения, курс и др. Политические предпочтения в процессе выборов могут находить объяснение с помощью различных теоретических моделей электорального поведения, в том числе социально-демографической, социологической, социальнопсихологической, когнитивной, партийно-идеологической идентификации, рационального выбора, экономического голосования. Политические предпочтения зависят от источников политической информации и уровня доверия к ним, таких как социальная среда (семья, друзья, сверстники и др.); СМИ (телевидение, радио, газеты и др.); цифровые коммуникации (сайты, социальные сети, блоги и др.). Сформированная в обществе система ценностей, таких как патриотизм, демократия, свобода, равенство, справедливость, традиции, также влияет на электоральный выбор избирателя. Исходя из отношения молодежи к институтам власти возможно провести сегментацию молодежи по политическим предпочтениям: это лояльная активная, лояльная пассивная, протестная пассивная, протестная активная молодежь. По отношению молодежи к электоральному участию можно выделить активных и ситуативных участников выборов, немотивированных и убежденных абсентеистов.

Динамика общественно-политических предпочтений студенческой молодежи в предстоящем электоральном цикле будет обусловлена социализацией, социально-экономическими изменениями и возрастающим влиянием цифровых коммуникаций. Сформированные в процессе социализации лояльность молодежи власти и патриотические ценности будут сдерживать расширение радикальных настроений и способствовать устойчивости политической системы. Уровень политической информированности, интенсивность взаимодействия в социальных сетях в значительной степени будут обусловливать содержание политических предпочтений. Социальные сети в предстоящем избирательном цикле будут ключевым каналом политической коммуникации и влияния на молодежную аудиторию, обеспечив широкое применение технологий сопряжения акций в онлайне и офлайне. Позитивная повестка предстоящих выборов и вдохновляющий образ будущего будут способствовать росту электорального участия молодежи. 


\section{Список литературы}

Алмонд Г.А. 1992. Гражданская культура и стабильность демократии. - Полис. Политические исследования. № 4. С. 45-77.

Ахременко А.С. 2006. Политический анализ и прогнозирование. М.: Гардарики. 333 c.

Банникова Л.Н., Боронина Л.Н., Вишневский Ю.Р. 2013. Новые явления в ценностных ориентациях студенчества. - Социс. Социологические исследования. № 2. C. 58-67.

Баскакова Ю.М., Дёмин А.А., Лашук Н.Е., Терентьева Н.Н. 2016. Американские практики электорального прогнозирования: доклад по результатам исследования. М.: ВЦИОМ. 39 с.

Беляева Н.М. 2014. Молодежь в общественно-политической жизни общества. Пермь: Изд-во ПГГПУ. 174 с.

Боброва Д.Н. 2016. Социальные факторы управления поведением молодых избирателей в региональных выборах: дис. ... К.соц.н. СПб. 183 с.

Бокарев В.А. 2008. Трансформация изменений социально-политических ориентаций молодежи на рубеже XX-XХІ вв. М.: Крылья. 184 с.

Будаева Ц.Б., Будаева Д.Ц. 2012. Электоральная активность и политические предпочтения молодежи Республики Бурятия. - Вестник Бурятского государственного университета. № 6. С. 208-211.

Букин В.П. 2009. Общественно-политические настроения и электоральные предпочтения молодежи российской провинции. - Известия высших учебных заведений. Поволжский регион. Гуманитарные науки. № 4(12). С. 161-172.

Гавра Д.П., Соколов Н.В. 1999. Исследование политических ориентаций. Социс. Социологические исследования. № 1. С. 66-77.

Горшков М.К., Шереги Ф.Э. 2010а. Ценностные ориентации, нравственные установки и гражданская активность молодежи. - Мониторинг общественного мнения: экономические и социальные перемены. № 1(95). С. 5-35.

Горшков М.К., Шереги Ф.Э. 2010б. Молодежь России: социологический портрет. М.: Изд-во ЦСПиМ. 592 с.

Гудков Л.Д., Дубин Б.В., Зоркая Н.А. 2011. Молодежь России. М.: Московская школа политических исследований. 96 с.

Дилигенский Г. 1994. Динамика и структурирование политических ориентаций в современной России. - Куда идет Россия? Альтернативы общественного развития (под общ. ред. Т.И. Заславской, Л.А. Арутюнян). М.: Интерпракс. C. $176-183$.

Ефанова Е.В. 2011. Молодежный экстремизм как форма политического протеста. - Власть . № 8. С. 30-33.

Звоновский В.Б. 2011. Прогнозирование электоральной активности на основе отчетов респондентов. - Мониторинг общественного мнения: экономические и социальные перемены. № 2(102). С. 5-15.

Зубок Ю.А., Сорокин О.В. 2010. Формирование политического сознания российской молодежи и обусловливающие его противоречия. - Социология власти. № 4. С. 6-15.

Карпенко О.М., Ламанов И.А. 2006. Молодежь в современном политическом процессе в России. М.: Изд-во СГУ. 560 с.

Малькевич А.А. 2007. Повышение электронной активности молодежи современной России: проблемы и пути решения. - Альманах современной науки и образования. Тамбов: Грамота. № 7(7): в 2 ч. Ч. II. С. 108-112.

Морозова Г.В. 2015. Студенческая молодежь: динамика политических интересов (региональный аспект). - Вестник Волгоградского государственного универcumema. Сер. 4. История. № 6(36). С. 127-134. 
Петросянц Д.В., Юшков И.В. 2016. Прогнозирование возможной динамики политической активности студенческой молодежи в новом электоральном цикле. - Региональные проблемы преобразования экономики. № 12. С. 133-142.

Пырма Р.В. 2017. Восстание поколения Z: новые политические радикалы. Гуманитарные науки. Вестник Финансового университета. Т. 7. № 2(26). С. 43-57.

Пырма Р.В. 2019. Электоральное участие молодежи в выборах президента России 2018 года. - Гуманитарные науки. Вестник Финансового университета. Т. 9. № 2(38). С. 50-57.

Сайганова Е.В. 2014. Специфика электорального поведения молодежи в структуре политической культуры общества. - Известия Саратовского универcumema. Сер. Социология. Политология. Т. 14. Вып. 2. С. 44-49.

Старцева С.Г. 2013. Динамика политических предпочтений региональной молодежи в условиях трансформации современного российского общества: дис. ... к.полит.н. СПб. 213 с.

Стегний В.Н. 2016. Политические ориентации студенческой молодежи: типы, факторы, особенности. - Вестник ПНИПУ. Социально-экономические науки. № 2. C. 8-17.

Тимофеев А.Ф., Пузиков В.Г. 2014. Политическое поведение и социально-экономические предпочтения в жизненной стратегии студенческой молодежи. Наука о человеке: гуманитарные исследования. № 1(15). С. 30-35.

Устинкина К.Г. 2014. Электоральное поведение российской молодежи. Проблемный анализ и государственно-управленческое проектирование. № 1(7). C. $139-145$.

Ценностные ориентации российской молодежи и реализация государственной молодежной политики: результаты исследования: монография (под общ. ред. С.В. Чуева). 2017. М.: ИД ГУУ. 131 с.

PYRMA Roman Vasil'evich, Cand.Sci. (Pol.Sci.), Associate Professor of the Department of Political Science, Faculty of Social Sciences and Mass Communications, Financial University under the Government of the Russian Federation (49 Leningradsky Ave, Moscow, Russia, 125993; pyrma@mail.ru)

\title{
THEORETICAL ASPECTS OF RESEARCH OF POLITICAL PREFERENCES OF RUSSIAN YOUTH
}

\begin{abstract}
The article provides an overview of scientific approaches to the study of political preferences of youth. The relevance of the topic is dictated by the upcoming election cycle. The author considers young people as a social group, potentially located to a significant increase in electoral activity. The electoral preferences of young people are characterized by a pronounced position; the decision is made in favor of a certain political subject with a set of ideas, values and resources. The movement of social moods and political preferences of young people in the upcoming federal elections is due to the socialization of the generation, socio-economic changes, the growing influence of digital communications and the proposed image of the future.
\end{abstract}

Keywords: youth, political preferences, electoral participation, political communications, electoral cycle 